\title{
Explicit Versus Implicit Modes of EFL Reading Literacy Instruction: Using Phonological Awareness With Adult Arab Learners
}

\author{
Mahmoud Ibrahim ${ }^{1}$ \\ ${ }^{1}$ English Langauge Institue, Universoty of Jeddah, KSA \\ Correspondence: Mahmoud Ibrahim, English Langauge Institue, Universoty of Jeddah, KSA. E-mail: \\ mahmoudahmad@aucegypt.edu
}

Received: July 21, 2018 Accepted: August 22, 2018 Online Published: August 24, 2018

doi: 10.5539/elt.v11n9p144 URL: http://doi.org/10.5539/elt.v11n9p144

\begin{abstract}
There is a strong belief among language teachers that intensive exposure to language alone can lead to acquisition. The present study is a qualitative- quantitative research design that used a quasi-experimental design to compare between the effectiveness of intensive exposure to language versus phonological awareness explicit instruction on adult Arab EFL learners' EFL reading literacy in a Saudi university context. The study is also concerned with Saudi adult learners' attitudes towards phonological awareness instruction. Participants $(\mathrm{N}=89)$ were all male students enrolled in an intensive EFL undergraduate program, where they were required to pass an intensive EFL course. Sample were randomly divided into a treatment group $(\mathrm{N}=47)$, who received phonological awareness treatment, and a control group $(\mathrm{N}=42)$ who were exposed to language intensively. Posttest findings confirmed the significant effect of phonological awareness instruction on the sample's EFL literacy. Moreover, positive attitudes towards the program were detected in the interviews held at the end of treatment. Therefore, the study recommended introducing phonological awareness instruction to develop Arab learners' EFL literacy.
\end{abstract}

Keywords: EFL literacy, phonological awareness, explicit instruction, implicit instruction

\section{Theoretical Background}

The National Reading Panel (2000) in the USA defined two major components of the process of reading: Word identification and word comprehension. Word identification is the ability to convert written letters into recognizable words, whereas word comprehension refers to understanding its meaning. Therefore, the ability to identify letters and convert them into words (a set of sounds) is a basic literacy skill, which is the focus of the present study. Although learning to read is a complex task, learning to read in a foreign language is even more. Reading literacy is defined in broad terms as the ability to respond appropriately to written language (Osailan, 2009). The National Adult Literacy Surveys (NALS), also in the U.S.A, defined literacy as "using printed and written information to function in society, to achieve one's goals, and to develop one's knowledge and potentials" (Proliteracy Worldwide, 2005). The literature is rich in studies that deal with developing children's EFL literacy (e.g., Cabell, Justice, Konold, \& McGinty, 2011; Levy, Gong, Hossels, Evans, \& Jared, 2006; Owodally, 2014; Whitehurst \& Lonigan, 1998). However, little research has contributed to develop adult learners' EFL literacy, especially in Arab university contexts.

The two major skills needed for children- as well as adults for developing literacy are oral language skills and code related skills (Cabell et al., 2011). While oral language skills are pertinent to expressive and receptive constituents of language form and content (syntax and vocabulary, for example), code related skills are those needed in order to "break the code" (Cabell et al., 2011). The current study focuses on the latter because it was the area where the sample was suffering (they could not even identify the English words in their textbooks).

On the one hand, implicit instruction, in general, utilizing intensive exposure to language- without explicit instruction- has always been argued to yield better results in language acquisition for all skills. Dekeyser (2007) claimed that intensive exposure to language could lead to language acquisition over time. The schism whether language skills should be taught explicitly or implicitly has been most eminent in the last decades of research in many language skills. For example, the disagreement about explicit versus induced teaching of grammar has not yet been fully resolved. Although some approaches and methods still prohibit the explicit teaching of grammar (e.g., the Natural Approach and Krashen's Model) and stress the importance of teaching language inductively, recent approaches (e.g., the communicative approach) argue that proper language acquisition cannot take place 
without Explicit Grammar Instruction (EGI) (Borg, 2009; Ellis, 2006). Another area other than grammar is pragmatics. Many studies (e.g., Fordyce, 2014; Jeon \& Kaya, 2006; Liao, 2009; Takahashi, 2010) compared between teaching pragmatics explicitly and implicitly in teaching various pragmatic abilities. They all confirm that explicit instruction of pragmatics has a much more significant effect than implicit teaching. However, the area of developing EFL literacy via explicit or implicit methods of instruction is not yet covered in the literature although there is a common belief among teachers that intensive exposure to language can develop learners' literacy. To conclude, Norris and Ortega (2000) conducted a meta-analysis of 49 studies on the effectiveness of second language teaching and concluded that explicit teaching - done through explaining and giving examples of the structure and presenting the rule to make it ready for use - is far more effective in acquiring the language skills than using implicit instruction only.

Although the literature is rich in studies that compare between implicit and explicit modes of teaching in many language skills (e.g., grammar, pragmatics and speaking), EFL literacy skills are hardly ever covered in this area. The current study follows on this track to fill in this gap of research; it compares between two different modes for developing adult learners' EFL literacy: Explicit instruction (using phonological awareness teaching) versus the implicit mode of literacy development (through intensive exposure to language).

On the other hand, there are two approaches for explicit instruction of EFL literacy: Alphabet knowledge and phonological awareness. Alphabet knowledge is defined by Puranik, Lonigan, and Kim (2011) as the learners' ability to identify the sounds and names of letters and how they can be combined to form a whole word. This, as explained by Phillips, Piasta, Anthony, Lonigan, and Francis (2012), is the strongest predictor of developing literacy. Knowing the name of each letter in the alphabet is argued by Share (2004) to facilitate creating the link between letters and sounds. Although alphabet knowledge is the major concern in pre-school instruction, Piasta and Wagner (2010) found little agreement on how to develop it effectively in the meta-analysis of more than 60 studies, which revealed that the effect of instruction on the learning outcomes differed according to various factors. Furthermore, Piasta and Wagner (2010) found negligible evidence of transfer of alphabet knowledge instruction to phonological skills or even those skills pertinent to spelling and reading. Moreover, the meta-analysis revealed that in spite of the general positive effect of the alphabet instruction on alphabet outcomes, the effect sizes were not reliable. Also, Foulin (2005) stated very clearly that the relationship between instruction of alphabetic knowledge alone and spelling and reading skills cannot be well-established.

The second approach, phonological awareness, is defined as "the awareness of constituent sounds of words in learning to read and spell” (Strickland \& Schickedanz, 2004). In the USA, the National Reading Panel (2000) stressed the findings that phonological awareness (PA) instruction had a significant positive effect on reading achievement as well as spelling skills. Although they are different from each other, phonological awareness instruction is different from phonics instruction. The former manipulating phonemes in spoken words, for example, blending sounds to form words (/t/-/o///d/ = "toad"), or segmenting words into phonemes ("shock" =/s/-/a/-/k/). Some PA programs teach children to use letters to manipulate phonemes in speech. This makes them more similar to phonics programs that may teach children to sound out and blend letters to decode words or to segment words into phonemes to spell words. However, phonics programs typically cover more than this and include instruction and practice in reading words in and out of text (Nunes, Ehri, Stahl, \& Willows, 2001). The current adopted the scope of PA since the objective the study was to offer a quick solution for the students who could not read English in their foundation classes.

Can reading literacy be developed through phonology? There are two schools that answer this question in two opposite directions. While Brady, Fowler, Stone and Winbury (1994) and Brennan and Ireson (1997) argued that teaching phonology had no significant effect on literacy development, Treiman and Baron (1983) and Cunningham (1990) argued there was a significant effect. Krashen (2004) and Freeman and Freeman (2000) demonstrated PA was not a cause for developing reading literacy, but a result of practicing reading. However, recently, more and more studies have confirmed the significant effect of phonological awareness on literacy development (e.g., Anthony \& Francis, 2005; Bing, Hui, \& Bingxia, 2013; Jacobi, 2008). Furthermore, the notion that phonology is strongly linked to spelling and, therefore, to reading literacy development was strongly proposed in many studies (Abu-Rabia \& Taha, 2006; Phillips, Clancy-Menchetti \& Christopher, 2008; Sprenger-Charolles, Siegel, Bechennec, \& Serniclaes, 2003). Therefore, due to the positive impact phonological awareness is claimed to have on developing literacy, it is used now as the medium of developing literacy in the U.S.A and the U.K. schools (Gregory, 2008; Harrison, 2004) as well as in Australia and New Zealand (Bowey, 2006).

Can these findings be generalized on the usefulness of phonological awareness on developing literacy in all EFL contexts? There is empirical evidence that phonological awareness instruction is efficient in developing EFL literacy among young learners from some backgrounds. For example, Sheu (2008) examined the effect of 
explicit phonological awareness instruction on 34 Taiwanese young learners. The study found that Taiwanese young learners, especially low achievers, improved their EFL literacy skills, especially in phoneme segmentation and vowel-consonant blending skills. Another similar study is Kodae and Laohawiriyanon (2011), which investigated the effect of phonological awareness instruction on Thai young learners' literacy. Again, a positive effect was detected.

Nevertheless, such findings do not conclude, by extension, whether or not phonological awareness instruction can be efficient with young or adult Arab learners. This is mainly because the English language is not easy to learn due to the complex nature of the consonant-vowel syllable structure (Goswami, 2007; Wyse \& Goswami, 2008). This is why the study is trying to answer the question whether phonological awareness instruction can be efficient with adult Arab learners or not.

The present study used PA to develop the sample's EFL literacy skills for two reasons. First, Saudi learners had been exposed in their early school education to the alphabet knowledge approach to develop their literacy. Therefore, the researcher decided to choose another approach. Learners might feel motivated to try "something new". Second, and more importantly, the study needed to find out the effectiveness of PA in the specific context of adult Arab learners. The material used for teaching was called Jolly Phonics. It is available for free on the internet. Teaching Literacy with Jolly Phonics (2014) explained that the course targeted developing five key literacy skills:

1) learning sounds of all the alphabet letters in addition to the diagraphs (e.g., sh, ai, ou, th...etc),

2) learning the various forms of letters,

3) learning blends (consonant clusters that blend together like ks, ts, pr...etc.),

4) learning segmentation,

5) and tricky words with irregular spelling.

Dixon, Schhagen and Seedhouse (2011) studied the impact of teaching Jolly Phonics on 500 young learners from 20 schools in India. Findings revealed that students who had studied Jolly Phonics achieved significantly better in the reading and writing tests than those who learnt in the traditional way. A similar study, which came up with quiet comparable findings, was carried out by Shepherd (2013) in Nigeria on a similar sample.

\section{Context of the Study}

One of the compulsory courses in the foundation year in Saudi universities is an intensive four-skill English language program. Some students in the foundation program, especially in remote undeveloped areas, lack basic literacy skills in English as a foreign Language (EFL). Because Tabouk University did not assign foundation year students to their classes on the basis of a placement test, but rather according to their departments, each class was extremely heterogeneous; while one EFL class contained advanced-level learners, it had learners who did not recognize the English alphabet, and therefore, could not read or write in English. In the University College of Umluj (Located in the south of Tabouk Region, KSA), all learners in the foundation year program $(\mathrm{N}=412)$ took a literacy test to scan those who could not read aloud an A1 reading passage (as per the Common European Framework of Reference). This initiative took place in the first semester in the academic year 2014/2015. Surprisingly, eighty-nine learners scored less than 20/100. The finding that some Saudi learners in the university level lack basic EFL literacy skills agrees with previous research done by Hall (2011) and by Osailan (2009) who concluded that Arab learners suffer from reading problems. In fact, Al-Issa and Dahan (2008) stated

It is important for teachers to find out about the students' literacy backgrounds, especially in an Arabic context where rote memorization is the main method of teaching in high schools and then use the students' strengths and weaknesses to develop appropriate curriculum.

Therefore, a solution was needed especially that the first level of the English course that learners study at Tabouk university was B2 (according to the CEFR). This meant that those who lacked EFL word identification literacy skills were doomed to fail the foundation year. The researcher suggested obliging illiterate students to take phonological awareness (PA) classes to teach them how to read in English.

Although plenty of research confirms the positive impact of PA instruction on developing literacy of English in native environments among young learners (Bowey, 2006; Donnell, 2007; Johnston \& Watson, 2005; Mohler, 2002; Salfer, 2006), research on the efficacy of PA on developing EFL literacy is hardly found. The current study attempted to fill in this research gap by investigating the effect of phonological awareness instruction on adult learners' EFL literacy. It follows then that this study aimed at answering the following research questions:

1) Which approach has a more significant effect on adult Saudi EFL learner's literacy: Explicit teaching of phonological awareness or intensive exposure to language in EFL classes? 
2) What is the attitude of Saudi university learners towards phonological awareness methodology used to develop EFL literacy?

\section{Hypotheses:}

The study hypothesized the that explicit teaching of phonological awareness had a more significant effect on developing the sample's EFL literacy than implicit instruction which was done through intensive exposure to EFL instruction. Another hypothesis the study held was that the sample, generally, had positive attitudes towards the phonological awareness instruction.

\section{Null Hypothesis:}

- The posttest scores reveal that the treatment group literacy skills have not developed in any positive way more significantly than the treatment group.

\section{Methods}

\subsection{Participants and Procedures}

Among more than 400 learners in the foundation year at the University College of Umluj (a branch of Tabouk University, Saudi Arabia), 89 learners scored less than 20/100 in the literacy test held by the university staff. Forty-two learners were randomly assigned to a control group, while the remaining 47 joined the treatment group. All learners were males, since the study took place in the males' campus and their ages ranged between seventeen and twenty. However, only three learners were 22 years old, but they did not complete the treatment (i.e., attrition). All learners had the same background in their high school. They all received almost the same governmental high school education in terms of course books, teaching methods and hours of instruction. Of the 47 participants in the treatment group, 11 students dropped out, while only nine in the control group did. This makes the final number of the treatment group 36 in comparison to 31 in the control group.

As mentioned before, all learners in the foundation year program were required to read aloud an A1 (as per the CEFR) passage made up of 100 words (see Appendix A). The passage was composed by the researcher to be constituted from basic-level vocabulary. Participants' readings were audio-recorded for further scoring. Test-takers took one mark for each word they could read aloud correctly even if the pronunciation was wrong. Some learners stated clearly that they were not able to read anything and quit the test because they did not even identify the English letters. Those who scored less than 20 (i.e., couldn't read correctly twenty words) were identified by the researcher to be illiterate, and therefore, needed intervention.

Participants in both the treatment group and the control group attended their normal intensive EFL classes for 15 hours a week, where they studied an EFL textbook to develop their English language skills. The University regulation imposed that the first level to which learners were admitted was B1, as per the CEFR. Therefore, according to their departments, foundation year students were assigned to study either B1, or B2 textbooks in their first semester.

On the other hand, the treatment group received explicit instruction (a total of 24 hours divided on 24 sessions over six weeks) of literacy using the phonological awareness methodology. Every session lasted for one hour where learners were receiving explicit instruction of a course book available for free on the internet with its audios and supplementary material called Jolly Phonics. It is worth-mentioning that this material was primarily designed for very young learners. The treatment group learners were randomly divided into two classes to receive instruction by two teachers other than the researcher to eliminate the Pygmalion effect (researcher's bias that may contaminate findings).

A typical lesson in the treatment would start with revising the previous input learners received, and then, the teacher would move to the new sounds. Input was not offered in alphabetical order, neither were letters introduced in the traditional way with their names. Instead, learners learnt how to associate each "letter shape" or orthographic representation to a sound. For example, the first lesson started with the sound /s/ represented by the shapes "s" and "S". The hissing sound of a snake and its drawing provided a vital supplement in this context. Then, learners were introduced to other components of the material like blending like $/ \mathrm{ks} /$ and segmentation in the same fashion. When students were asking about the names of letters, teachers made it clear that they were not concerned with names of letters, but with sounds. By the end of every class. Learners would memorize some vocabulary with the letters they had studied. It is worth-mentioning that the sounds are arranged in a way-different from the traditional alphabetical order- in order to allow earlier ability of combining sounds into words. Also, every class must have audios that come with the material for allowing the students to listen to native production of the sounds in focus. By the end of the treatment, they were able to identify the sounds into letters and were able to write, upon dictation, some words correctly, especially the words they studied in their course. They were also able to identify and read words that 
contain blending and segmentation. However, they were not able to identify name of letters.

As for the control group, they used to attend their normal EFL intensive classes. Most of the time, the teacher would explain the lesson and they might sometimes write in their books and ask the teacher some questions. Some teachers used repetition drills in their classrooms so that weak learners could catch what they say. A typical lesson in the control group consisted of the activities in New Headway (Fourth Edition) by Soars, Soars, and Maris (2012). Every unit in this textbook consists of lexico-grammar activities presented with listening and speaking skills. Therefore, a typical lesson would include a conversation activity from the book that contained grammar and vocabulary. Learners listened and tried to read this conversation. Then, the teacher explained the grammar and vocabulary. However, it is important to mention that in such classes, learners who lacked basic literacy skills could hardly follow, and therefore, did not participate in any activities. Teachers believed that with time, they will develop literacy skills and be able to catch up.

Then, all participants in the treatment and the control groups took the same pretest again, but this time as a posttest. Moreover, participants who took the treatment were required to answer a questionnaire during interviews held immediately after taking the test. It is important to mention that this questionnaire was also answered by the control group students after they had received remedial phonological awareness instruction to equate them with their colleagues who benefitted from the treatment. This makes the total number of participants who took the questionnaire 62 because 5 learners dropped out. The questionnaire was made up of five items on a Likert scale (See Appendix B).

\subsection{Instruments}

The study used two main tools for measurement: The reading literacy test and the Likert-scale questionnaires, which were answered in structured interviews. The skill that students lacked was the ability to read words in their textbooks. That is, the literacy skill targeted was simply to be able to interpret written letters into identifiable words and to read them aloud. If students acquired this skill, they would be able to cope in intensive EFL classes and understand the subject matter provided. Therefore, the reading literacy test was an oral one. It simply required test-takers to read aloud a one-hundred-word passage (See appendix A). The passage level was A1- as per the CEFR. Pronunciation mistakes were completely tolerated. A test-taker would take one mark for every correct word he could read. Participants' responses were audio-recorded in order to obtain an accurate scoring.

The questionnaire was made up of five Likert scale items (See Appendix B). The reason why questionnaires were answered in interviews is that the researcher wanted to make sure participants gave valid answers for the questions and that they understood every question. Questions were administered in Arabic because learners' EFL levels did not allow them yet to understand and respond to questions in English appropriately. Accuracy of translation was verified via the back-translation technique. In order to measure the reliability of the questionnaire, Cronbach's Alpha was obtained. Cronbach's Alpha scored 0.87 , which means the scale is highly reliable.

Table 1. Consistency and validity for the questionnaire items

\begin{tabular}{|c|c|c|}
\hline question & $\begin{array}{l}\text { Correlation between item } \\
\text { and total } \bullet\end{array}$ & $\begin{array}{l}\text { Cronbach's Alpha if Item } \\
\bullet \bullet \text { Deleted }\end{array}$ \\
\hline 1- I have not learnt English before in this methodology. & $0.700^{* *}$ & 0.839 \\
\hline 2- Jolly Phonics handouts were interesting and fun. & $0.726 * *$ & 0.835 \\
\hline $\begin{array}{l}\text { 3- I feel my English language skills have improved } \\
\text { because of this teaching methodology. }\end{array}$ & $0.636^{* *}$ & 0.854 \\
\hline $\begin{array}{l}\text { 4- It was easy for me to understand the subject matter and } \\
\text { digest information. }\end{array}$ & $0.609 * *$ & 0.860 \\
\hline $\begin{array}{l}\text { 5- I learnt in this methodology better than the one in } \\
\text { which I learnt before at school. }\end{array}$ & $0.814 * *$ & 0.813 \\
\hline Total Scale & & 0.869 \\
\hline
\end{tabular}

** The correlation is significant at 0.01 level.

- The value of correlation between the question and the sum of all questions. This measures the internal validity.

-• The value of Cronbach's Alpha after removing the question: The consistency of the question with the other questions. 
Further calculations were made to ensure the internal consistency of the questionnaire. Since the questionnaire investigated the attitudes of the learners towards the treatment, it was not possible to pilot it with a similar population because this similar population would need to take the treatment first. Therefore, internal consistency was calculated out of the answers participants already gave. One item (it was the fourth question) was found out to be inconsistent with the other items, so it was deleted. For each question, the value of Cronbach's Alpha (if the question is removed) is less than the total value, which indicates the internal consistency of the questions of the Scale. Also, the correlation is significant at 0.01 level, which indicates the items are highly valid.

\section{Results}

Before applying the treatment on the experimental group, both groups took the same pretest. T-test was used to calculate if there is a statistical difference in means of the scores obtained by both groups. Table 2 illustrates that there was no significant difference between mean scores between both groups in the pretest $(t=1.8$ with $p=0.076)$.

Table 2. Results of the T-test for the pretest scores in both groups

\begin{tabular}{llllllll}
\hline Treatment & Group & $\mathrm{N}$ & Mean & Std. Deviation & ${ }^{*} \mathrm{t}_{65}$ & Sig. (p-value) & Conclusion \\
\hline \multirow{2}{*}{ Pretest } & Experimental & 36 & 4.33 & 3.59 & -1.805 & 0.076 & \multirow{2}{*}{ Not Sig. } \\
& Control & 31 & 6.32 & 5.37 & & & \\
\hline
\end{tabular}

$* \mathbf{t}_{65}$ is the value of the t- statistic at (65) degree of freedom.

First, in order to investigate the effect of the explicit PA instruction on EFL literacy, paired sample t-test was used to calculate the difference in means between pretest and posttest results in the treatment group. Table 3 illustrates that $t$ value was 13.9 with a significant p-value of 0.001 (which is less than 0.05 ). in other words, there is a significant difference between the mean score of the Posttest and the mean of the Pretest in favor of the Posttest. This means that the explicit instruction of phonological awareness had a significant positive effect on Saudi EFL learners' literacy.

Table 3. Paired sample T-test for the treatment group

\begin{tabular}{|c|c|c|c|c|c|c|c|c|}
\hline \multirow[b]{2}{*}{ Group } & \multirow[b]{2}{*}{ Treatment } & \multirow[b]{2}{*}{$\mathrm{N}$} & \multirow[b]{2}{*}{ Mean } & \multirow[b]{2}{*}{ Std. Deviation } & \multicolumn{4}{|c|}{ Paired Differences } \\
\hline & & & & & Mean & Std. Error of the Mean & $* t_{35}$ & $\begin{array}{l}\text { Sig. } \\
\text { (p-value) }\end{array}$ \\
\hline \multirow{2}{*}{ Experimental } & Post & 36 & 42.64 & 17.06 & \multirow{2}{*}{38.31} & \multirow{2}{*}{2.75} & \multirow{2}{*}{13.911} & \multirow{2}{*}{0.001} \\
\hline & Pre & 36 & 4.33 & 3.59 & & & & \\
\hline
\end{tabular}

$* \mathbf{t}_{35}$ is the value of the $\mathrm{t}$ - statistic at (35) degree of freedom.

Second, in contrast, comparison between the mean scores of the pretest and posttest results of the control group revealed there was no statistically significant difference. Table 4 shows that $\mathrm{p}$ value was 0.82 , which is higher than 0.05 .

Table 4. Paired Sample T-test for the Control Group

\begin{tabular}{lllllllll}
\hline \multirow{2}{*}{ Group } & Treatment & $\mathrm{N}$ & Mean & Std. Deviation & \multicolumn{2}{c}{ Paired Differences } \\
& & & & & Mean & Std. Error of the Mean & $*_{30}$ & $\begin{array}{l}\text { Sig. } \\
\text { (p-value) }\end{array}$ \\
\hline \multirow{2}{*}{ Control } & Post & 31 & 6.39 & 6.01 & 0.065 & 0.321 & 0.201 & 0.842 \\
& Pre & 31 & 6.32 & 5.37 & & & \\
\hline
\end{tabular}

Third, t-test was also used to compare between posttest mean scores of the treatment group and the control group to 
find out if there was a statistically significant difference between them. T-test scored 11.92 with a P-value of 0.001 (less than 0.05), as illustrated in Table 5. This clearly shows there is a statistically significant difference between both groups giving evidence that using phonological awareness has a significant effect on the sample's EFL literacy.

Table 5. Comparing posttest scores in both groups

\begin{tabular}{lllllll}
\hline Treatment & Group & $\mathrm{N}$ & Mean & $\mathrm{SD}$ & $* \mathrm{t}_{44.73}$ & Sig. (p-value) \\
\hline \multirow{2}{*}{ post test } & Experimental & 36 & 42.64 & 17.06 & \multirow{2}{*}{11.920} & \multirow{2}{*}{0.001} \\
& Control & 31 & 6.39 & 6.01 & & \\
\hline
\end{tabular}

In order to calculate effect size, Cohen's $\mathrm{d}$ was calculated using the $t$ test value for a between-subject $t$ test and the degrees of freedom. The value of Cohen's $d$ was 3.567 making an effect size of 0.872 , which indicates a large effect size.

Table 6. Codes for Descriptive Data Analysis

\begin{tabular}{lllll}
\hline Response & Strongly Agree & Agree & Disagree & Strongly Disagree \\
\hline weight & 4 & 3 & 2 & 1 \\
\hline
\end{tabular}

For the purpose of obtaining descriptive findings for the responses on the Likert scale, responses took the codes in Table 6. Moreover, table 7 illustrates the results that were obtained when the responses were analyzed.

Table 7. Descriptive statistics for questionnaire items

\begin{tabular}{|c|c|c|c|c|c|c|c|c|c|c|c|c|}
\hline \multirow[t]{2}{*}{ Questions } & \multicolumn{2}{|c|}{$\begin{array}{l}\text { Strongly } \\
\text { Disagree }\end{array}$} & \multicolumn{2}{|c|}{ Disagree } & \multicolumn{2}{|c|}{ Agree } & \multicolumn{2}{|c|}{$\begin{array}{l}\text { Strongly } \\
\text { Agree }\end{array}$} & \multirow{2}{*}{$\begin{array}{l}\text { Weighted } \\
\text { Mean }\end{array}$} & \multirow{2}{*}{$\begin{array}{l}\text { Std. } \\
\text { Deviation }\end{array}$} & \multirow{2}{*}{$\begin{array}{l}\text { Overall } \\
\text { Response } \\
\text { Mean) }\end{array}$} & \multirow[t]{2}{*}{ Priority } \\
\hline & f & $\%$ & $\mathrm{f}$ & $\%$ & $\mathrm{f}$ & $\%$ & $\mathrm{f}$ & $\%$ & & & & \\
\hline 1 & 0 & 0.0 & 10 & 16.1 & 21 & 33.9 & 31 & 50.0 & 3.34 & 0.75 & Strongly Agree & 3 \\
\hline 2 & 3 & 4.8 & 6 & 9.7 & 23 & 37.1 & 30 & 48.4 & 3.29 & 0.84 & Strongly Agree & 5 \\
\hline 3 & 1 & 1.6 & 5 & 8.1 & 28 & 45.2 & 28 & 45.2 & 3.34 & 0.70 & Strongly Agree & 3 \\
\hline 4 & 0 & 0.0 & 6 & 9.7 & 24 & 38.7 & 32 & 51.6 & 3.42 & 0.67 & Strongly Agree & 2 \\
\hline 5 & 0 & 0.0 & 6 & 9.7 & 16 & 25.8 & 40 & 64.5 & 3.55 & 0.67 & Strongly Agree & 1 \\
\hline Total & 4 & 1.29 & 33 & 10.65 & 112 & 36.13 & 161 & 51.94 & 3.39 & 0.59 & Strongly Agree & \\
\hline
\end{tabular}

The first question was intended to investigate if the sample had already studied PA before. Descriptive statistics showed that students mostly had not learnt literacy using PA before $(\mathrm{M}=3.34$, SD 0.75$)$. The second question investigated participants' attitudes towards Jolly Phonics handouts. Generally, participants had positive attitudes; the largest proportion agreed and strongly agreed to the statement that the handouts were interesting and fun $(\mathrm{M}=$ $3.29, \mathrm{SD}=0.84)$. The third question aimed at allowing each participant to reflect on his own learning outcomes. With a medium of $3.34(\mathrm{SD}=0.7)$, participants expressed that they felt their EFL skills had developed due to the treatment. The fourth question investigated the level of difficulty the sample faced while learning PA. Participants explained that they found it easy to understand the subject matter and achieve learning outcomes $(\mathrm{M}=3.4, \mathrm{SD}=$ 0.67). The last question is important in terms of preference and comparison between learning in the traditional way versus the PA. Participants explicitly showed that they had learnt literacy using PA better that the way they had learnt in schools $(\mathrm{M}=3.55, \mathrm{SD}=0.67)$.

\section{Discussion}

The study aimed at comparing the effectiveness of intensive exposure to language with the explicit instruction of PA on Arab learners EFL reading literacy. It also aimed at investigating their attitudes towards the PA methodology, given that they have never tried it before. In broad terms, the study findings concluded the positive 
effect of PA instruction on developing adult Arab learners' EFL literacy. Such findings are consistent with a considerable line of studies that examined the efficacy of PA instruction in teaching literacy with young learners like Bing et al. (2013), and Phillips et al. (2008), and Kodae and Laohawiriyanon (2011).

Although PA instruction proved effective with learners from certain backgrounds, it is not necessarily effective with all learners from all backgrounds (Goswami, 2008). This is primarily due to the phonological differences inherent in the features of both English- the target language (as an Indo-European language) and Arabic (as a Semitic language). The current study provided ample evidence that teaching literacy through phonological awareness to Arab learners is not only possible, but also more effective than traditional methodologies.

In contrast to explicit instruction of literacy, intensive exposure to language in the EFL classrooms did not yield any remarkable results in EFL literacy development. For decades, L2 researchers like Dekyser (2007) tried hard to avoid explicit instruction of language. However, the literature in the last two decades is stressing the importance of explicit instruction for various language skills. The current study is consistent with this line of studies that includes grammar (Borg, 2009; Ellis, 2006) and pragmatics (Fordyce, 2014; Takahashi, 2010). Participants' answers to the interview questions reveal that participants stated they had developed their EFL literacy through PA. This is consistent with many studies (e.g., Abu-Rabia \& Taha, 2006; Bing et al., 2013; Phillips et al., 2008) which confirm the positive effect of PA instruction on literacy development.

As mentioned before, due to linguistic reasons, the success of PA instruction with a certain group of learners from a certain background does not guarantee its success with other backgrounds (Goswami, 2007; Wyse \& Goswami, 2008). Questionnaire findings also suggest evidence for the suitability of PA instruction for developing literacy of Arab learners. In fact, a significant proportion of learners expressed that they had learnt in PA methodology better than the one they had used at school. This is consistent with findings from Sheu (2008) and from Kodae and Laohawiriyanon (2011) [25] on Taiwanese's and Thai learners in respective order.

One of the most important implications of the study findings is pertinent to EFL teaching in Saudi Arabia. Interview findings confirmed that participants had never learnt literacy using phonological awareness. The study, therefore, suggests introducing PA instruction in early school education or in universities to develop EFL literacy. The study also stress, in this regard, the importance of offering practical remedial reading literacy classes for EFL illiterate learners in Saudi contexts. The present study opens horizons for further research to examine the effectiveness of PA instruction also on developing Arab learners' literacy in other foreign languages from different origins like French, which is a Latin language. Only because it was effective with EFL literacy is not enough evidence it can be the same with other languages.

Generally, the interviews detected that participants had positive attitudes towards PA instruction. This is particularly important because they have never tried this method of learning or teaching before and because the material they studied was primarily designed for young learners. Not only did they find the handouts "interesting and fun", but also they described their learning experience to be "easy", which can encourage other teachers in similar contexts to try the same solution to address the problem.

\section{Implications, limitations and Recommendations for Further Research}

To start with, on the pedagogical level, Saudi universities are encouraged to administer EFL literacy tests with the foundation year learners especially in beginning levels. Those who fail to pass these tests shall be admitted into PA literacy programs before joining their foundation year EFL courses. Moreover, teachers and program directors should be made aware that intensive exposure to language is barely enough to acquire a language skill. That is, teachers and program directors should be pedagogically directed to investigate and cure areas of weakness in language skills learners have. Second, on the methodological level, phonological awareness instruction is strongly recommended for Arab learners to develop their EFL literacy. Most, if not all, Arab schools now still use the alphabet knowledge approach to develop young learners' literacy whether in L1 or in L2. Empirical evidence now backs up attempts to change this tradition. In addition, Saudi universities are encouraged to develop their own phonological awareness materials or handouts that would suit the age groups of their learners. Unfortunately, most of the available material currently found in the market is designed for very young learners. These methodological implications require stakeholders to train teachers to use phonological awareness in EFL classrooms and to educate teachers on the effectiveness of this approach. Third, research implications can extend to include advancing the approaches used to promote literacy in Arabic using the PA approaches among Arab speakers. In the Arab world, learners are still learning Arabic, whether as a foreign language or as a second language, in the alphabet- knowledge approach. However, more innovative approaches to teach Arabic can be introduced and investigated for effectiveness in comparison to the traditional approaches already in use.

On top of the recommendations for research comes the priority to compare the effectiveness of explicit versus 
implicit modes of language instruction. Although the literature is rich in studies that compare explicit versus implicit modes of grammar instruction, other skills are still hardly covered. Also, on another different level, teaching literacy in Arabic as a first or second language still takes place using the traditional approaches. For this regard, first, PA instruction needs to have a feasible framework that is based on empirical backgrounds. Second, the effectiveness of using PA in developing Arabic, as a first or a second language, needs to be compared with the effectiveness of using the alphabet knowledge approach. Third, the arrangement of sounds needs to be reconsidered in comparison to the arrangement of the alphabet to allow the Arabic learners earlier ability to produce words while learning. Finally, teachers' attitudes need to be investigated in qualitative manners to find out how they actually manage the problem of EFL illiterate learners in their classes, especially if these classes are intermediate. Finding out such attitudes is important when they compared and contrasted with the recommendations suggested by recent research so that stakeholders and program directors can take steps to solve the problem.

It shall be noted that the study findings have some limitations. First, given that the study was carried out in a Saudi context, findings can hardly be generalized among non-Arab EFL learners because the effectiveness of using PA depends, as previously stated, to a great extent on L1 phonological system. Another limitation is pertinent to the gender of the learners. That is, all the participants were males because of the gender segregation policy in the Saudi educational system. This raises questions around the reliability of the findings investigating the participants' attitudes towards the program had the sample been purely females or mixed.

\section{Conclusions}

Empirical evidence hardly supports the view that exposure to language alone is enough for language acquisition in the skills studies so far including pragmatics, grammar, or reading literacy. Also, teachers need to be updated that recent research backs up the view that explicit instruction yields better results in language learning in various language skills. More and more studies are being published about the effectiveness of explicit instruction of language skills used updated methodology. At a time when EFL reading literacy is becoming a serious problem in many Arab countries including Saudi Arabia, universities should consider updating their teaching philosophies so that they can introduce more innovative solutions for such a persistent problem.

\section{References}

Abu-Rabia, S., \& Taha, H. (2006). Phonological errors predominate in Arabic spelling across grades 1-9. Journal of Psycholinguistic Research, 35, 167-188. https://doi.org/10.1007/s10936-005-9010-7

Al-Issa, A., \& Dahan, L.S. (2008). Prior knowledge and writing in the college EFL composition classroom. In C. Coombe, A. Jendli, \& P. Davidson (Eds.), Teaching Writing Skills in EFL. TESOL Arabia, Dubai.

Anthony, J., \& Francis, D. (2005). Development of phonological awareness. Current Directions in Psychological Science, 14(5), 255-259. https://doi.org/10.1111/j.0963-7214.2005.00376.x

Bing, S., Hui, Z., \& Bingxia, Z. (2013). Effects of English phonological awareness training on Chinese child EFL learners' literacy development. Canadian Social Science, 9 (1), 56-64.

Borg, S. (2009). Language teacher cognition. In A. Burns, \& J. C. Richards (Eds.), The Cambridge guide to second language teacher education (pp. 163-171). New York: Cambridge University Press.

Bowey, J. A. (2006). Need for systematic synthetic phonics teaching within the early reading curriculum. The Australian Psychological Society, 41(2), 79-84. https://doi.org/10.1080/00050060600610334

Brady, S., Fowler, A., Stone, B., \& Winbury, N. (1994). Training phonological awareness: A study with inner-city kindergarten children. Annals of Dyslexia, 44, 26-59. https://doi.org/10.1007/BF02648154

Brennan, F., \& Ireson, J. (1997). Training phonological awareness: A study to evaluate the effects of a program of metalinguistic games in kindergarten. Reading and Writing, 9, 241-263. https://doi.org/10.1023/ A:1007979321948

Cabell, S. Q., Justice, L. M., Konold, T. R., \& McGinty, A. S. (2011). Profiles of emergent literacy skills among children who are risk for academic difficulties. Early Childhood Research Quarterly, 26, 1-14. https://doi.org/10.1016/j.ecresq.2010.05.003

Cunningham, A. E. (1990). Explicit versus implicit instruction in phonemic awareness. Journal of Experimental Child Psychology, 50, 429-444. https://doi.org/10.1016/0022-0965(90)90079-N

DeKeyser, R. (Ed.). (2007). Practice in a second language. Cambridge, UK: Cambridge University Press. https://doi.org/10.1017/CBO9780511667275 
Dixon, P., Schagen, I., \& Seedhouse, P. (2011). The impact of an intervention on children's reading and spelling ability in low-income schools in India. School Effectiveness and School Improvement, 22(4), 461-482. https://doi.org/10.1080/09243453.2011.625125

Donnell, W. (2007). The effects of multisensory vowel instruction during word study for third-grade students. Reading Research Quarterly, 42(4), 468-471. https://doi.org/10.1598/RRQ.42.4.2

Ellis, R. (2006). Current issues in the teaching of grammar: An SLA perspective. Tesol Quarterly, 40(1), 83-107. https://doi.org/10.2307/40264512

Fordyce, K. (2014). The differential effects of explicit and implicit instructions on EFL learners' use of epistemic stance. Applied Linguistics, 35(1), 6-28. https://doi.org/10.1093/applin/ams076

Foulin, J. N. (2005). Why is letter-name knowledge such a good predictor of learning to read? Reading and Writing, 18(2), 129-155. https://doi.org/10.1007/s11145-004-5892-2

Freeman, D. E., \& Freeman, Y. S. (2000). Teaching Reading in Multilingual Classrooms. Portsmouth, NH: Heinemann.

Goswami, U. (2007). Learning to read across languages: The role of phonics and synthetic phonics. In K. Goouch, \& A. Lambirth (Eds.), Understanding phonics and teaching of reading: Critical perspective (pp. 124-143). England: Open University Press.

Gregory, E. (2008). Learning to read in a new language. London: Saga Publications Ltd.

Hall, K. L. (2011). Teaching composition and rhetoric to Arab EFL learners. In C. Gitsaki (Ed.), Teaching and learning in the Arab World (pp. 421-431). Bern, Peter Lang.

Harrison, C. (2004). Understanding reading development. London: Sage Publication. https://doi.org/ $10.4135 / 9781446215401 . n 6$

Jacobi, V. (2008). The Effects of a Phonological Awareness on the Decoding Skills of Kindergarten Children (Doctoral thesis). University of Louisville, Louisville

Jeon, E. H., \& Kaya, T. (2006). Effects of L2 instruction on interlanguage pragmatic development: A meta-analysis. In J. M. Norris, \& L. Ortega (Eds.), Synthesizing Research on Language Learning and Teaching. John Benjamins. https://doi.org/10.1075/11lt.13.10jeo

Johnston, R. S., \& Watson, J. E. (2005). The effects of synthetic phonics teaching on reading and spelling attainment. Unpublished manuscript, Department of Psychology, University of Hull, Kingston upon Hull, England.

Kodae, H., \& Laohawiriyanon, C. (2011). Effects of intensive phonics instruction on reading and spelling attainment of Thai grade 5 learners with reading difficulties. Paper presented at the third International Conference on Humanities and Social Sciences, Prince of Songkla University, Hat Yai, Sogkhla, Thailand.

Krashen, S. (2004). Applying the comprehension hypothesis. Paper presented at the $13^{\text {th }}$ International Symposium and Book Fair on Language Teaching (English Teachers Association of the Republic of China). Taipei, Taiwan.

Levy, B. A., Gong, Z., Hessels, S., Evans, M. A., \& Jared, D. (2006). Understanding print: Early reading development and the contributions of home literacy experiences. Journal of Experimental Psychology, 93(1), 63-93. https://doi.org/10.1016/j.jecp.2005.07.003

Liao, S. (2009). Variation in the use of discourse markers by Chinese teaching assistants in the US. Journal of Pragmatics, 417, 1313-28. https://doi.org/10.1016/j.pragma.2008.09.026

Mohler, G. M. (2002). The effect of direct instruction in phonemic awareness, multisensory phonics, and fluency on the basic reading skills of low-ability seventh grade students. Unpublished doctoral dissertation. The University of Nebraska, Nebraska.

National Reading Panel. (2000). Teaching children to read: An evidence-based assessment of scientific research literature on reading and its implications for reading instruction. Washington, DC: National Institute of Child Health and Human Development.

Norris, J., \& Ortega, L. (2000). Effectiveness of L2 Instruction: A research synthesis and quantitative meta-analysis. Language Learning, 50, 417-428. https://doi.org/10.1111/0023-8333.00136

Nunes, S., Ehri, L., Stahl, S., \& Willows, D. (2001). Systematic phonics instruction helps students learn to read: Evidence from the National Reading Panel's meta-analysis. Review of Educational Research, 71(3), 
393-447. https://doi.org/10.3102/00346543071003393

Osailan, G. (2009). The English literacy experiences of advanced Saudi EFL professionals in the United States. Unpublished Doctoral Dissertation. Indiana University of Pennsylvania. Retrieved from $\mathrm{http}: / /$ knowledge.library.iup.edu/cgi/viewcontent.cgi?article=1264\&context=etd

Owodally, A. (2014). Code-related aspects of emergent literacy: How prepared are preschoolers for the challenges of literacy in an EFL context? Early Child Development and Care, 185(4), 511-529.

Phillips, B. M., Clancy-Menchetti, J., \& Christopher, J. L. (2008). Successful phonological awareness instruction with preschool children: Lesson from the classroom. Topics in Early Childhood Special Education, 28, 3-17. https://doi.org/10.1177/0271121407313813

Phillips, B. M., Piasta, S. B., Anthony, J. L., Lonigan, C. J., \& Francis, D. J. (2012). IRTs of the ABCs: Children's letter name acquisition. Journal of School Psychology, 50, 461-481. https://doi.org/10.1016/ j.jsp.2012.05.002

Piasta, S., \& Wagner, R. (2010). Developing early literacy skills: A meta-analysis of alphabet learning and instruction. Reading Research Quarterly, 45(1), 8-38. https://doi.org/10.1598/RRQ.45.1.2

Proliteracy Worldwide. (2005). Adult literacy figures nosurprise to Proliteracy Worldwide: What's new. Syracuse, NY: Proliteracy Worldwide.

Puranik, C. S., Lonigan, C. J., \& Kim, Y-S. (2011). Contributions of emergent literacy skills to name writing, letter writing, and spelling in school children. Early Childhood Research Quarterly, 26, 465-474. https://doi.org/10.1016/j.ecresq.2011.03.002

Salfer, N. (2006). Implementing a multisensory reading program for kindergarten students in charter school. Unpublished manuscript. Nova University, Florida, United States.

Share, D. L. (2004). Knowing letter names and learning letter sounds: A causal connection. Journal of Experimental Child Psychology, 88, 213-233. https://doi.org/10.1016/j.jecp.2004.03.005

Shepherd, S. (2013). Does intensive synthetic phonics instruction improve the literacy skills of primary one children in cross river state? Unpublished MA thesis. Nigeria University. Nigeria.

Sheu, W. (2008). The effect of explicit phonics instruction on the development of phonological awareness. Unpublished MA thesis. Institute of English national Taiwan Normal University, Taiwan

Soars, L. \& Soars, J., \& Maris, A. (2012). New Headway (4th ed.). Oxford: Oxford University Press.

Sprenger-Charolles, L., Siegel, L., Bechennec, D., \& Serniclaes, W. (2003). Development of phonological and orthographic processing in reading aloud, in silent reading, and in spelling: A four-year longitudinal study. Journal of Experimental Child Psychology, 84, 194-217. https://doi.org/10.1016/S0022-0965(03)00024-9

Strickland, D., \& Schickedanz, J. (2004). Learning about print in preschool: Working with letters, words, and beginning links with phonemic awareness. Newark, DE: International Reading Association.

Takahashi, S. (2010). The effect of pragmatic instruction on speech act performance. In A. Martínez-Flor, \& E. Uso' -Juan (Eds.), Speech act performance: Theoretical, empirical and methodological issues (pp. 127-140). Amsterdam/ Philadelphia: John Benjamins. https://doi.org/10.1075/1lt.26.08tak

Teaching Literacy with Jolly Phonics. (2014, December). Retrieved from http://jollyleraning.co.uk/overview-about-jolly-phonics

Treiman, R., \& Baron, J. (1983). Phonemic analysis training helps children benefit from spelling-sound rules. Memory and Cognition, 11, 382-389. https://doi.org/10.3758/BF03202453

Whitehurst, G. J., \& Lonigan, C. J. (1998). Child development and emergent literacy. Child Development, 69, 848-872. https://doi.org/10.1111/j.1467-8624.1998.tb06247.x

Wyse, D., \& Goswami, U. (2008). Synthetic phonics and the teaching of reading. British Educational Research Journal, 34(6), 691-710. https://doi.org/10.1080/01411920802268912 


\section{Appendices}

\section{Appendix A: Reading-aloud Test:}

Please read the following paragraph aloud. Pronunciation mistakes are tolerated:

My name is Nawaf Al-Harby. I am from Umluj, Saudi Arabia. I am a student at Umluj University College in the first year. My mother is an Arabic teacher. She works at a school near the house where we live, but my father is a police man. He works at the police station in the north of the city. I have one brother and two sisters. They are all older than me. I love them and they love me too. I would like to graduate in four years and become a good doctor or a great teacher like my mother.

\section{Appendix B: Interview Questions:}

Answer the Following Question by showing how much you agree to these statements:

\begin{tabular}{|c|c|c|c|c|}
\hline Question & $\begin{array}{l}\text { Strongly } \\
\text { Agree }\end{array}$ & Agree & $\begin{array}{c}\text { Disagree } \\
\dot{1}\end{array}$ & $\begin{array}{l}\text { Strongly } \\
\text { Disagree } \\
\dot{1} \text { ici }\end{array}$ \\
\hline السؤال & أوافق بثدة & & & اعثدة \\
\hline
\end{tabular}

I have not learnt English before in this methodology.

لم أتعلم الإنجليزية من قبل بهذه الطريقة

Jolly Phonics handouts were interesting and fun.

كانت المذكرة التي درسناها شيقة وممتعة

I feel my English language skills have improved because of this teaching methodology.

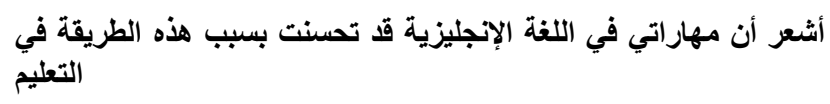

It was easy for me to understand the subject matter and digest information.

كان سهلا علي أن فهم المعلومات المقدمة.

I learnt in this methodology better than the one in which I learnt before at school/

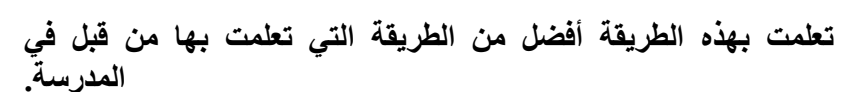

\section{Copyrights}

Copyright for this article is retained by the author(s), with first publication rights granted to the journal.

This is an open-access article distributed under the terms and conditions of the Creative Commons Attribution license (http://creativecommons.org/licenses/by/4.0/). 